\title{
3 The Descriptive Turn in German Nature-Oriented Neue Sachlichkeit (1913-1933)
}

\section{An Essay on Nonhuman Literary Genres}

\section{Michael Karlsson Pedersen}

Not all literary genres have the same interest in the nonhuman. It is possible to make a clear-cut division between literature oriented toward the human and literature oriented toward the nonhuman. Or, as Ursula K. Le Guin reflects in her illuminating piece "The Critics, the Monsters, and the Fantasists" (2007), it is possible to distinguish between realistic-anthropocentric fiction and fantastic-ecocentric fiction. Although such a distinction could be seen as exclusionary, it does in fact include a wide range of texts:

Realistic fiction is relentlessly focused on human behavior and psychology. "The proper study of mankind is Man" [quotation from Alexander Pope]. When fiction disobeys Pope and begins to include the Other, it begins to shade into the ghost story, the horror story, the animal story, or science fiction, or fantasy; it begins the movement outward to the not-entirely-human. Even "regional" fiction, always looked at disparagingly by the modernists, is part of this movement, sliding from human psychology into that which contains it, the landscape.

(Le Guin 87)

When one is interested in the nonhuman (from animals to landscapes), one must-if following Le Guin—abandon realist fiction altogether: "What fantasy generally does that the realistic novel generally cannot do is include the nonhuman as essential. ... To include anything on equal footing with the human, as equal in importance, is to abandon realism" (87). But in the interest of making such a turn to nonhuman genres of sci-fi, fantasy, horror, regional, or nature-oriented writing, Le Guin's thematic focus must be complemented by a formal reflection: what literary devices do such genres use to bring the nonhuman into their texts? I will argue that the concept of description is of vital importance.

In order to reflect and elaborate on the role of description in nonhuman genres, I want to engage with the turn to description in the nature-oriented Neue Sachlichkeit or New Objectivity in German literature from 1913 to 
1933. This descriptive turn can be seen in different nonhuman genres such as Alfred Döblin's science fiction novel Berge Meere und Giganten (1924) and Wilhelm Lehmann's nature diary Bukolisches Tagebuch (1927-1932). I will deal with both examples later in this essay. Furthermore, under the banner of a new metaphysical naturalism, Döblin develops a theory of description focusing on how the nonhuman can be approached in a literary text, a theory that then serves as the basic model for how description of nonhuman environments and objects is used in the nature-oriented Neue Sachlichkeit. But to appreciate the scope and applicability of Döblin's descriptive theory, I want to underline its resonance with more recent object-oriented and materialist theories by Graham Harman and Jane Bennett. Here a connection between nonhuman ontologies of objects and things and different types of descriptive devices is proposed as the basis for a dual model of horizontal and vertical description, which can be used to reframe and clarify Döblin's theory and thus the use of description of nonhuman environments and objects in the Neue Sachlichkeit. Thus, avoiding the often-sole focus on Anglophone literature by exploring the German context, my chapter brings forth new comparative possibilities for literary scholarship engaging with the nonhuman. ${ }^{1}$

My chapter will therefore begin with an introduction to Harman and Bennett in order to outline two types of description (vertical and horizontal), which are given a brief example through $\mathrm{H}$. P. Lovecraft's horror novel At the Mountains of Madness (1931/1936). I then turn to Döblin's theory of description, his metaphysical naturalism, which is compared with the weird realism proposed by Harman. I conclude this section by showing how Döblin's new naturalism is not only found in his theoretical reflections but also in his fiction, notably the sci-fi novel Berge Meere und Giganten. In the following section, I give a closer textual analysis of Lehmann's nature diary Bukolisches Tagebuch and how it puts to use the vertical and horizontal ways of describing the nonhuman world. In conclusion, I highlight how the turn to nonhuman genres can bring about a new comparative history of literature.

\section{Materialism/Immaterialism, Literary Description, and H. P. Lovecraft}

In the history of literary theory, nonhuman spaces such as natural landscapes and their material objects have traditionally been seen as the province of description. Ruth Ronen attests to and criticizes this long history, where the "world of objects" has traditionally been assumed to be handled by descriptive practices (275). Her point is that the divide between narration and description, between human actions and nonhuman objects, has resulted in downgrading description to something unchanging, passive and ultimately superfluous to the story (cf. 276). Such a concept of description is insufficient, as Ronen herself notes: "a landscape can be described as an 
active agent" (276). Following the old metaphysical hierarchy between subject and object, the devaluation of description stems from its connection with objects and their anthropocentric connotations of passivity and inertness. Consequently, to place a concept of description at the heart of nonhuman genres necessitates that not only description itself but also the nonhuman objects themselves be rethought as something vital and active. This means that the nonhuman (ontology), description (aesthetics)—and especially the relation between the two-must be conceptualized anew. The task of overcoming the old metaphysical dualism in order to do justice to nonhuman objects and descriptive language has been undertaken by new theories of object-oriented ontology and new materialism.

In his book Immaterialism: Objects and Social Theory (2016) Graham Harman makes a helpful distinction between new materialism and immaterialism (object-oriented ontology), that is, between immanent relationality and transcendent essentiality (cf. 14-20), which sums up two current ways of theorizing about objects and things. The materialist model stresses connectability and relationality between things in an agential matrix, whereas the immaterialist model stresses the autonomy, inaccessibility, and non-relationality of things. Harman represents the second position, as the title of his 2016 book shows, and Jane Bennett is representative of the first position. In this section, I will combine these two ontologies of things and relate them to an aesthetic vocabulary proposed by Harman in his study on H. P. Lovecraft, Weird Realism: Lovecraft and Philosophy (2012). The aim is to establish a relation between nonhuman ontology and descriptive techniques used in literary texts.

In Vibrant Matter: A Political Ecology of Things (2010), Bennett highlights that a thing has "an active, earthy, not-quite-human capaciousness (vibrant matter)" (3). This vital materialism inherent in things produces concrete effects through what she terms a "particular assemblage:" independent of human interaction, disparate things-because of their material vibrancyconnect and relate with each other, producing an assemblage of "vivid entities" (5). In a particularly rich and sensuous description, Bennett shows what such an assemblage of things looks like:

When the materiality of the glove, the rat, the pollen, the bottle cap, and the stick started to shimmer and spark, it was in part because of the contingent tableau that they formed with each other, with the street, with the weather that morning, with me. For had the sun not glinted on the black glove, I might not have seen the rat; had the rat not been there, I might not have noted the bottle cap, and so on.

Bennett's description shows how the material agency of each particular thing is directed at creating connections with other things, which in the end form a "tableau." The world of things also wants to connect with humans, 
but such a flat and nonhierarchical ontology does not privilege the human bystander over the bottle cap or vice versa. Rather, both are engaged in a centerless relational bonding, which is not mastered by anyone of the two, human or bottle cap.

Against Bennett's model of thing-relationality, Harman proposes a notion of non-relationality inspired by Heidegger: "This deeply nonrelational conception of the reality of things is the heart of object-oriented philosophy" ("The Well-Wrought Broken Hammer" 187). Harman argues that neither practical use nor theoretical speculation can exhaust the reality of the thing, as its essence is always retained in an obscure area beyond human reach. He explains this through the example of a chair:

To sit in a chair does not exhaust its reality any more than visual observation of the chair ever does. Human theory and human praxis are both prone to surprises from sudden eruptions of unknown properties from the chair-being of the chair, which recedes into the darkness beyond all human access. Pushing things another step further, it must be seen that the same holds for inanimate entities, since the chair and floor distort one another no less than humans distort the chair.

(Weird Realism 15-16)

Instead of Bennett's emphasis on how things seek each other out, forming assemblages through which they produce material effects, Harman argues that, regardless of the relationality of matter, what produces effect is the fact that the thing avoids or recedes from any connection.

Although there is a basic theoretical difference between the materialist and the immaterialist stance, these two models of objects can be productively related. When Harman moves from theory to offering actual examples of objects, he in fact describes how an object (chair) relates to another object (floor). Such object-object connections provide a common ground with Bennett's thing-assemblage, although Harman would argue that such connections never exhaust the reality of the objects themselves. Thus, a synthesis of Harman and Bennett stresses how material relationality and immaterial non-relationality are both inseparable aspects and possibilities of the thing, which can change from the act of seeking material relations with other things to the act of receding from these very relations, beyond and into immaterial obscurity. As Bennett herself briefly states at the beginning of Vibrant Matter, things feature both a "negative power or recalcitrance" and "a positive, productive power of their own" (1).

The importance of maintaining both the negative-resisting and positiveproductive sides of things becomes even more urgent when dealing with literature. This is evident in Harman's Weird Realism: Lovecraft and Philosophy, which translates nonhuman ontology into categories of aesthetic form by using the American writer H. P. Lovecraft as an example. For Harman, Lovecraft is a writer of gaps (2), that is, of both vertical 
gaps and horizontal gaps. The first kind adheres to the Heideggerian gap between "the real and the sensual" (4), that is, between withdrawnness (non-relationality) and sensuous availability. The second, horizontal kind describes the Husserlian gap between "objects and their qualities" (4), that is, between "the relatively durable objects of our perception and their swirling kaleidoscope of shifting properties" (5). In short, the vertical gap marks an immaterialist stance, which was shown above, and the horizontal gap a materialist position, which is represented by Bennett. This "dual polarization" (4) of the object thus enables Harman to understand how Lovecraft produces a certain kind of weird realism.

Based on this ontology Harman develops a corresponding pair of formalstylistic concepts: vertical and horizontal styles of description. The vertical gap expresses itself in an allusive or indirect style, because language as such can never access the immaterial reality of the object. As Harman writes, "[the] inability to make the things-in-themselves directly present does not forbid us from having indirect access to them" (17). That is exactly what Lovecraft does when faced with the noumenal ungraspability of, for instance, the Cthulhu-monster; he succeeds in describing it through allusion: "Lovecraft can allude to the physical form of Cthulhu even while cancelling the literal terms of the description" (17). Although this "vertical" or allusive aspect of Lovecraft's style, that is, "the gap he produces between an ungraspable thing and the vaguely relevant descriptions that the narrator is able to attempt" (24), fills up most of Harman's reflections, there is an equally important horizontal aspect, which is consistent with Bennett's materialism. Here the importance of maintaining both the positive-relational and the negative-transcendent side of the object becomes clear, as they correspond to two stylistic aspects found in Lovecraft's prose. If the vertical description expresses language falling short of the object, the horizontal style of description is indeed "overloaded by a gluttonous excess of surfaces and aspects of the thing" (25). The horizontal description expresses a surplus of specificity; it embraces the fact that the object offers a multitude of sensuous impressions and qualities, which overwhelms language. One could also think of Bennett's description of the tableau of things, which draws its power from the material specificity of each thing. This is not the vertical description of the immaterial-noumenal side with its shying away from any attempts at grasping its essential being but rather the horizontal description of the extensive material-phenomenal side of Lovecraft's weird monsters, landscapes, and cities.

To make the distinction between the two types of description more concrete, I will discuss a brief example from Lovecraft's novel At the Mountains of Madness (1936). The novel centers on a scientific expedition to the Antarctic told in retrospect by one of the survivors, a geologist. In this "white, aeon-dead world of the ultimate south" (19), the expedition discovers a mysterious mountain range, which hides "a Palaeogaean megalopolis" (66). It is the encounter with this inhuman city and its ancient 
forms of architecture and sculpture that sets off both horizontal and vertical descriptions. Lovecraft writes:

The Cyclopean massiveness and gigantism of everything about us became curiously oppressive; and there was something vaguely but deeply inhuman in all the contours, dimensions, proportions, decorations, and constructional nuances of the blasphemously archaic stonework. We soon realized, from what the carvings revealed, that this monstrous city was many million years old.

In the quote, the concrete architecture with its sculptural aspects is at the same time traits of an inhuman entity, which underscores the city's ungraspable and incomprehensible nature. There is a simultaneity of horizontal description of stonework ("contours, dimensions, proportions, decorations") and of vertical description of its liminality ("vaguely but deeply inhuman"). For Lovecraft, the inhuman is the prehuman in a both temporal-geological and spatial-object-oriented sense, testifying to the limits of human understanding and descriptive powers. Still, the narrator amasses a great deal of details from the various sculptures and architecture, although he knows he cannot comprehend or even represent them meaningfully: "It is useless to try to compare this art with any represented in our museums. Those who see our photographs will probably find its closest analogue in certain grotesque conceptions of the most daring futurists" (78). The dynamism of Lovecraft's descriptive prose is built on this ongoing slide from horizontal to vertical descriptions, from the manifold material contours of the thing to its negative, non-comparable, and unfathomable essence.

The non-relationality of objects must necessarily make language fall short; it thus expresses itself through vague and evasive language (vertical style) as was seen in the emphasis on the inhuman nature of the ancient city. But the material side of objects can also take over the descriptive language in such a way that it expresses an abundance of concrete descriptions (for instance, the futurist sculptural design found in the city). Thus, different types of description adhere to sides of the thing, and, as stated above, the position I propose recognizes the importance of maintaining both sides. In fact, as was also clear in the Lovecraft example, it is the very conflict between the two sides of the object that infuses the literary text with a productive, descriptive tension: the ungraspability or inhumaneness of things elicits multiple and puzzling descriptions, a move that then inevitability ends in resignation and an emphasizing of the unknown and indescribable nature of things.

Although based on Lovecraft's prose, the concepts of vertical and horizontal description offer an aesthetic vocabulary to be used in other literary contexts. I will now turn to a specific moment in German literary history, where the concept of description surfaced and nonhuman literary genres such as science fiction and nature writing became dominant. It is 
my contention that the descriptive practices developed at this time can be reconstructed through a constellation of vertical and horizontal styles, as found in Lovecraft's prose.

\section{Alfred Döblin's Metaphysical Naturalism}

The movement of Neue Sachlichkeit or New Objectivity, which was the dominant trend in German literature in the second half of the 1920s, included a wide range of authors and painters, who all reacted against expressionism. Instead of a visionary and often mythic-apocalyptic depiction of torn subjectivity in a language heavy with imagery and with the catastrophe of war as background, the authors of the Neue Sachlichkeit turned to a description of the tangible, concrete world around them. ${ }^{2}$ The term Sachlichkeit or Objectivity named not only this turn away from expressionistic subjectivism and visionary imagery, but also a new attitude toward the world at hand: cold, distanced, and sober, that is, sachlich.

The post-expressionistic literature of the Neue Sachlichkeit is not, however, one movement in unison. There are, according to Hans Dieter Schäfer, two overall strands within the movement (cf. Wilhelm Lehmann 125 and "Naturdichtung und Neue Sachlichkeit" 375). One oriented toward urban spaces (particularly Berlin), which is represented in documentary newspaper reportage and the contemporary novel. Realistic depictions of contemporary life in the city take center stage in literature, as can be found in Egon Erwin Kisch's literary reporting gathered in The Wild Reporter (Der rasende Reporter, 1924) and Erich Kästner's novel Fabian: The Story of a Moralist (Fabian. Die Geschichte eines Moralisten, 1931). The other is oriented toward natural landscapes and objects outside the city center depicted in more "timeless" genres such as poetry and short prose pieces. The latter strand is of interest because it combines a descriptive style with attention to the nonhuman world; that is, it resorts to description of nonhuman environments and objects (as opposed to the eminently subject-centric form of description found in the urban strand of the Neue Sachlichkeit). This turn is especially evident in the writings of Alfred Döblin, who as early as 1913 and in the following years developed a literary program termed Neue Naturalismus, highly influenced by the architect Adolf Loos and his seminal "Ornament and Crime" ("Ornament und Verbrechen," 1908/1910), which made him a "pioneer of the literary Neue Sachlichkeit" (Sander 140). Other writers, who can be said to follow this neusachliche program of description of nonhuman environments and objects, are Wilhelm Lehmann and Ernst Jünger; I will return to Lehmann in the next section and give an example from his Bucolic Diary. In this section, I will present the theoretical architecture of Döblin's literary program of a new naturalism, which I take to be the standard model for description in the nature-oriented Neue Sachlichkeit, and compare it with the concepts of vertical/horizontal description from the previous section. 
It is worth noting that Döblin's discussion of a new naturalism is not always consistent but takes different turns dependent on the context. In the following, I will reconstruct the turn to reality as involving a twofold argument. First, a literary argument: a turn away from psychology and subjectivism as well as decorative, metaphorical language and toward hard empiricism and descriptive practices. Second, a philosophical argument: an attempt to bridge the subject-object divide through a notion of externalization, whereby a spiritual dimension is added to the empirical world. In the end, Döblin's proposed new naturalism can be understood as a kind of spiritual or metaphysical naturalism.

The first statement published by Döblin, which inaugurates the turn to concrete reality, can be found in his article "Berlin Program" ("An Romanautoren und ihre Kritiker. Berliner Programm") from 1913. The article ends with the following call for a new naturalism in the arts:

Naturalism is not a historical "ism," but the heavy shower that always has to break out over art and break into it. Psychologism, eroticism, must be swept away; release of self, release of the author, depersonalization. The earth must steam again. Away from humans! Courage for kinetic imagination and for recognizing the unbelievable real contours! Factual imagination!

The ethos of Sachlichkeit, that is, of hard objectivity, cold factualness, and a critique of subject-centric referentiality is clearly present in Döblin's naturalism. This ethos stresses an anti-anthropocentric stance, which pushes literature away from privileging the human realm. The naturalism Döblin introduces is not a return to a former period of literary history (the epoch of Zola) but rather a new demand laid on art to turn to the actual physical world into which it is situated. Tatsachenphantasie: a new factual or empirical imagination forces literature to rediscover the physical world anew. Döblin opposes his call for concrete empiricism to useless, decorative imagery (with an echo from Loos) as well as of the use of psychology and romantic inwardness, which was present in neoromantic literature dominant from the turn of the nineteenth century. A typical example of this kind of literature is Hermann Hesse's coming-of-age novel Peter Camenzind from 1904 about the lonely sufferings and wanderings of a young man, a clear descendant of the romantic poet J. F. von Eichendorff's nameless protagonist in the novella The Memoirs of a Good-for-Nothing (Aus dem Leben eines Taugenichts, 1826). Instead of this focus on a single person (Hesse's novel is narrated in the first person and centers on the development of a single individual) or on indirect-metaphorical language (in for instance expressionistic poetry) as the basis for literature, Döblin favors a hard, direct prose, whose focus is "soulless [entseelte] reality" (121), a reality that presents "the whole world with the multiplicity of its dimensions" (122), which entails "the fanaticism 
of externalization: I am not me, but the street, the lanterns, this and that event, nothing more" (122). The new naturalist program expresses a turn to nonhuman reality, which at the same time critiques a certain notion of the human as an isolated psychological entity, which is typically seen as central to literature. In his 1913-program, the two sides of Döblin's argument for a new naturalism are already present: the anti-romantic or descriptive stance and the emphasis on the human subject as decentralized or externalized. This argument is then expanded upon and reiterated in later essays and talks.

In a critique of Filippo Tommaso Marinetti from the same year, Döblin again expresses his naturalist "desire for reality" ("Futuristische Worttechnik" 116). He emphasizes that literature must deal with the things directly and not treat them as "helpless" material for building various analogies and constructing surprising imagery: "The things are unique; a belly is a belly and not a watering can: That is the A B C of the naturalist, of the real direct artist" (117). It is through this mix of anti-psychological and anti-decorative stances and a focus on the concreteness of the actual world that description gains new importance. This becomes the main concern in Döblin's article "Commitment to Naturalism" ("Bekenntnis zum Naturalismus") from 1920. As described above, the beginning of the twentieth century was dominated by the idea that art was the realm of psychology and interiority. This realm of "true art" was seen as wholly incompatible with the superficiality of description, and it was thus deemed inadequate as a device for literature:

For a number of years in literature "description" [Beschreiben], "depiction" [Schildern] have been abhorred as hostile to art. ... The rejection of description stems from the general feeling that spiritualization is currently the most important elemental impulse of the arts; everywhere the material, "realistic" ballast is thrown overboard; there is an irrepressible demand to directly present living souls.

Any attempt at focusing on objects and their details is seen in the eye of the true, psychological artist as a shallow and empty empiricism, it is simply an expression of "Soullessness [Seellosigkeit]" (292). Because of this critique laid on descriptive practices, Döblin must elaborate on his previous notion of reality as "soulless," an argument already contained in his notion of the subject as externalized.

Döblin does not seek to establish a binary between spirit and world, subject and object, spiritualized art and descriptive art. Rather, Döblin stresses that the details of the empirical world-which was otherwise understood as "soulless reality"- are "not soulless" (292) at all. Instead, he now speaks of "soul carrier [Seelenträger]" (292), that is, every described object carries with it a spiritual side; every object is simultaneously empirical 
and non-empirical or spiritual. Thus, description is an empirically bound form of spiritualization, a way of dealing with the soul, not as something situated inherently in the interiority of human beings, but rather as something living in the nonhuman objects of the world, being embedded in the physical world at large. In the 1913-program, this was termed "fanaticism of externalization," subjectivity is turned inside out. The term "soulless reality" was then used by Döblin to distance himself from a reality completely reduced to psychology and interiority (as in the neoromantic literature); however, reality itself is not reducible to a purely empirical world. Rather, reality is seen as a kind of objectified or exteriorized spirituality. Döblin's turn to naturalism is not a way of proposing a descriptive practice that depicts the world by amassing details and collecting them into a kind of protocol, as Klaus Müller-Salget has also emphasized (cf. 11). Description must rather take notice of a spiritualized or metaphysical empiricism: every real-physical object has an unreal-spiritual side.

Döblin's call for a new naturalism thus entails both a concept of reality, which can be termed metaphysical naturalism, and a corresponding emphasis on the need for a descriptive practice at the center of literature. The very architecture of this argument (from philosophy to aesthetics) as well as the idea of a dual nature of things - a physical and metaphysical side of objects-mimic in a significant way the materialist and immaterialist stances proposed by Harman and Bennett. Indeed, with the theory of vertical and horizontal description, which connects to the negative-closed and positiveopen side of the object, a vocabulary is offered that can summarize what Döblin tried to develop. Metaphysical naturalism is, in other words, very close to what Harman calls "weird realism in which real individual objects resist all forms of causal or cognitive mastery" (Weird Realism 188); that is, the weird realist text offers objects that have an autonomy of their own. But, as was made clear in the blending of Harman's immaterialism and Bennett's materialism, it is a weird realism that not only describes these resisting objects (vertical style) but also the many facets and details of material objects (horizontal style). Döblin's metaphysical naturalism is built on a similar conceptual architecture, but its relation between vertical and horizontal description is negotiated in different ways by different texts within the nature-oriented Neue Sachlichkeit, as we shall see.

Thus, it is worth noting that Döblin did not only theorize about a new naturalism but also translated these reflections into literary praxis. Of special interest is his science fiction novel, Mountains Seas and Giants (Berge Meere und Giganten) from 1924, which depicts a 500-year timespan of humankind's evolution from the twenty-third to the twenty-eight century. ${ }^{4}$ The novel centers on humankind's technological endeavors and capabilities: because of overpopulation a plan is formed to de-ice Greenland in order to obtain more land. As this hugely ambitious plan succeeds-Greenland is indeed made into two great islands fit for habitation-unexpected side effects occur: old dinosaur-like life forms, which slumbered under the ice, as 
well as new monstrous animals begin to appear. These latter so-called giants then begin to wreak havoc on the civilization that created them-nature strikes back in the form of huge monsters.

Not unlike Lovecraft's expedition to the Antarctic in At the Mountains of Madness, Döblin's narrative of human hubris is built on a combination of naturalistic facts and monstrous depictions. Thus, the novel uses a great deal of geological information, which-as Ritchie Robertson has pointed out-creates a dehumanized and hard-to-grasp "poetry of geology" (222). The specificity of such a horizontal-naturalist mode of description borders, however, on a mere amassing of facts of the nonhuman world, as is clear in the initial description of Greenland: "Greenland, the massif made of gneiss and granite, pushed itself, a wedge, from the pole into the Atlantic waters. It covered two million square kilometers" (363). But the confident and precise descriptions of this massive and self-contained world are effectively contrasted by the depiction of rising monstrous beings, the vertical description of which underlines the difficulties in grasping their heterogenous bodies made of both organic-biological and inorganicmineralogical matter:

They were beings the likes of which the Earth had never seen before. The waters the salts earth gathered themselves around bare limbs, heads bones teeth tails vertebrae, around fern leaves stamping parts root stumps; often it grew into creatures that resembled the ancient times of the Earth, often strange beings shaped themselves, absorbed the earth, danced.

The difficulties in describing these grotesque beings is not only present in the emphasis on their weirdly mixed material bodies (the mineralogy of bone and teeth clashes with the biological matter of leaves and roots), which are uniquely new life forms but also in the analogy to the ancient geological times of the earth, well beyond the time span of human civilization. Of course, the difference to Lovecraft's monsters is quite clear as his old ones are prehumen entities, whereas Döblin's are newly made as a consequence of human action. Still, both underscore the ancient qualities and appearances of their monsters, which reflect their inherent material strangeness and ungraspability. In sum, Döblin's novel serves as an example of his own metaphysical naturalism through its mingling of detailed naturalisthorizontal descriptions of geological processes and of metaphysical-vertical depictions of materially heterogenic monsters.

Döblin's science fiction novel thus uses vertical and horizontal descriptions as a means of staging a clash between human civilization and a monstrous, revengeful nature. As in Lovecraft's novel, the emphasis is laid on the fact that the earth does not exist only for scientific and technological exploitation. Much in the same ecological and critical vein, though without 
monstrosities and exotic setting, Wilhelm Lehmann explores the more mundane nature of Northern Germany in his short prose pieces. I will now turn to Lehmann's Bucolic Diary to give a more elaborate example of how vertical and horizontal descriptions are used in the nature-oriented Neue Sachlichkeit.

\section{Worlds Apart: Wilhelm Lehmann's Bucolic Diary}

Wilhelm Lehmann's Bucolic Diary was published as a column between 1927 and 1932 in the newspaper Die Grüne Post and later collected into a book and published in 1948. The pages of the diary register a post-anthropocentric notion of reality, where the human as such is radically decentered and pushed almost into oblivion, and the life of nonhuman phenomena takes center stage. Lehmann's nature diary is a mix of close, detailed observations of botanical, zoological, entomological, geological, and meteorological phenomena and reflections on these nonhuman phenomena in relation to the human world. As such, Lehmann's diary is the kind of nature writing or environmental nonfiction often associated with American authors such as H. D. Thoreau, John Muir, and Aldo Leopold (cf. Goodbody). One of the basic definitions of the genre of nature writing, as Lawrence Buell argues, is indeed that "[the] nonhuman environment is present not merely as a framing device but as a presence that begins to suggest that human history is implicated in natural history" (The Environmental Imagination 7). In Lehmann's nature diary, this is not only suggested but acted out, as the nonhuman world of natural history takes center stage, and humans are left in the periphery, as mere observers.

A very basic assumption that underpins Lehmann's relation to nonhuman reality is what could be called an ontological biocentric stance, as it is for instance expressed in the following short reflection from the Bucolic Diary:

He [human being, MKP] cannot help himself, he has to immerse everything in his world. ... He may do so, if only he sometimes thinks in deep amazement that snake and bird, mosquito and grass, jellyfish and water and cloud are worlds apart and ward off the merry intruder.

The notion of "worlds apart" expresses the core of Lehmann's thinking: although humans must see everything in relation to themselves, as for instance by representing the nonhuman world in language, they must never forget the autonomy or "warding off" of the natural world. The inherently anthropomorphizing nature of humans' relation to the nonhuman reality is, however, acknowledged and cherished by Lehmann: human presence in nature is seen as a "merry" intrusion, not a destructive act; he especially privileges the poetic act of naming as a primordial way of relating to or 
"intruding” upon nature: “And a playful humanization [Vermenschlichung] never speaks from the authentic names, rather they rise from deepest immersion [Versenkung], from the most serious closeness" (208-9). But the previous quote does, at the same time, highlight the fact that it is the difference between human and nonhuman that produces "deep amazement." This suggests a link between Harman's vertical gap between "real" and "sensual" and Lehmann's gap between "worlds apart" and human intrusion or naming, as both emphasize the inherently negative or autonomous nature of the object, which—as Lehmann puts it—-wards off" human access and language. The task of the poet is then to gather and describe this dynamic of "deep amazement" in language through the act of naming, channeling both the "deepest immersion" (horizontal materialism) and a sense of ontological limitation, "worlds apart" (vertical immaterialism).

A telling example of this poetic endeavor to describe how natural objects are both material and immaterial can be found in an entry from a cold March day by the sea in 1928 :

The earth is strong here, its bones are protruding, the granite boulder blocks, and the ocean is so sure it can play with the sweetest colors, just as the tiger stains his skin with the red of the nasturtium blossom. Everything turns back and meets. The cloud of the sky meets itself as puddle of the earth, and the plumage of the brambling is reflected in the bowl of the crab, which the gull consumed.

The striking thing about this description is how every object is seeking out other objects, "meeting" and "playing" with each other, which in effect produces an assemblage of material interconnectedness: the granite stones of the earth protrude into the air, the surface of the ocean plays with the color of the light. This is a clear example of a horizontal description, whose focus is on how an object has-in Bennett's sense-a vital material agency, which enables it to connect with other objects. Not unlike Bennett's own "contingent tableau," Lehmann here grasps a similar moment of positive, material connectivity. His descriptive practice is horizontal and relational, governed by the circular law of "everything turns back and meets." Central is Lehmann's use of the word "play" ("Spiel"). The natural space is disclosed as a kind of playground, where every object acts freely and independently, without being there for either use or exploitation. As such, the inter-play of natural objects emphasizes their free aesthetic and sensuous nature: the ocean plays with color and the tiger plays with nasturtium.

The concreteness of these horizontal descriptions, which for Lehmann are descriptions of object-object play, is however loosened, when the material-relational law of "everything turns back and meets" is further developed as a dematerializing law of mirroring: the circularity produces concrete connectivity, but it also abstracts the integrity of object itself. The 
objects meet each other, but in doing so they also mirror and reflect each other, whereby the object itself transgresses and in effect loses itself: the cloud of the sky is transformed into a puddle on the ground, that is, it meets itself as an otherness, just as the brambling is transformed into an image in the emptied out back bowl of the crab. The affirmative playful relationality of objects is at the same time dematerialized and slides into a non-relational otherness. The horizontal playground is turned into a vertical mirroring space, where the object is drawn away from itself, abstracted and transformed into something else. The natural object may then show itself in its relational play mode but can at the same time escape into its nonrelational otherness by giving up its material integrity, by becoming in a sense abstract and immaterial: when the cloud and the brambling transform and dematerialize, they confirm their inexhaustible nature for otherness.

Lehmann's short prose piece confirms the connection between the aesthetic-horizontal inter-play of objects and the vertical mirroring or dematerialization of the object itself. The juxtaposition of concrete objects implies a sense of sliding into absence. As such, the assemblage of objectobject-play builds the empirical foundation for a sense of "deep amazement," which in effect hints at and thus maintains the negative ungraspability of the object, a "world apart." The nature of Lehmann's descriptive text rests on this sliding connection: the combination of minute detail and the depiction of a natural scene such as the shore offers a realm of contingent phenomena, which are then formatted through ontological laws of first object-play and then object-mirroring. As Döblin argued, the new naturalism is always also a kind of metaphysical naturalism, not only a description of material details but also a description of their transcendent otherness. Lehmann's nature diary never leaves the boundedness of a specific place and its material dynamisms, but at the same time it exposes the inherent otherness of this otherwise mundane landscape.

\section{Conclusion}

In the interest of examining and expanding upon a notion of nonhuman genres, my chapter has developed a theory of description based on recent object-oriented and materialist theories. At the center of this theory is the relation between ontology and aesthetics, which suggests that the being of objects as such calls for specific modes of literary description. In other words, ontological categories are turned into aesthetic ones: the materialism/ immaterialism-divide translates into the opposition between vertical and horizontal description.

To give credence to such a theory, I discussed two examples from German literature of the early twentieth century. It thus became clear that the categories developed in contemporary philosophy were compatible and indeed helped to illuminate the specific kind of description and naturalism proposed by Döblin and later adopted by the nature-oriented Neue 
Sachlichkeit. This new metaphysical naturalism negotiated the relation between materialism and immaterialism in a new way: Lehmann's prose laid great emphasis on the mundane reality of natural phenomena and spaces but also maintained a vanishing point into which such reality could escape. This dynamism was made clear in an example taken from the Bucolic Diary, where material connectedness of object-object-play gave way to a dematerialized mirroring of the object, which thus evades a final fixation and exhaustion in a described scene. The act of describing the nonhuman is thus both an engagement with the material richness of its various facets as well as an acknowledgment of its autonomous nature.

Metaphysical naturalism in the German context demonstrates the potential of prose centered on the description of nonhuman reality. The internal dynamics of these texts are not based on plot or human protagonists but rather on the life of nonhuman phenomena and spaces such as Lehmann's “worlds apart” of the North German landscape and Döblin's giants rising from a de-iced Greenland as well as Lovecraft's inhuman city in the Antarctic. Indeed, the focus on nonhuman genres discloses new national and even transnational correspondences, which transcend traditional genre boundaries. It seems, for instance, that nature writing and fantastic literature are very closely linked, as Le Guin also hinted at. From the perspective of the nonhuman, it thus makes sense to place Lehmann's pastoral depictions of the Northern German landscape in relation to J. R. R. Tolkien's green and idyllic Middle Earth from the Lord of the Rings-trilogy (written 19371949, published 1954-1955). Or, it is productive to relate Ernst Jünger's sense of the natural elements' prehuman powers in his travels to Norway in 1935 (Myrdun, published 1943) or Brazil in 1936 (Atlantische Fabrt, published 1947) to Lovecraft's depictions of an utterly alien world in At the Mountains of Madness. A genuine possibility then arises for rediscovering and rewriting literary history from the perspective of nonhuman genres, revealing surprising correspondences across languages, genres, and literary traditions. The example of the descriptive turn in German literature becomes, then, part of a larger attempt at placing the nonhuman environment and its plenitude of objects at the center of literary endeavors.

\section{Notes}

1 The need to inhabit more comparative modes of dealing with the nonhuman in literary studies thus transcending the dominant trend of Anglocentrism is for instance voiced by ecocritic Lawrence Buell in his essay "Ecocriticism: Some Emerging Trends" (cf. 107).

2 See, for instance, Georg Heym's poem "Der Krieg” from 1911 or Georg Trakl's poem "Grodek" from 1914.

3 All the following German quotes are translated by me.

4 It is worth noting that the literary interest in vast temporal scales and how they can offer a new perspective on human civilization is also present in British sci-fi writer and philosopher Olaf Stapledon's novel from 1930, Last and First Men: A Story of the Near and Far Future. Stapledon's cosmic vision builds a narrative 
that spans two billion years and depicts the colonization of other planets, closing with the end of the human species.

\section{References}

Bennett, Jane. Vibrant Matter: A Political Ecology of Things. Duke University Press, 2010.

Buell, Lawrence. The Environmental Imagination: Thoreau, Nature Writing and the Formation of American Culture. Harvard University Press, 1995.

Buell, Lawrence. "Ecocriticism: Some Emerging Trends." Qui Parle, vol. 19, no. 2, 2011, pp. 87-115.

Döblin, Alfred. “An Romanautoren und ihre Kritiker: Berliner Programm.” Schriften zu Ästhetik, Poetik und Literatur, edited by Erich Kleinschmidt, Walter-Verlag, 1989, pp. 119-123.

Döblin, Alfred. "Bekenntnis zum Naturalismus." Kleine Schriften I: 1902-1921, edited by Anthony W. Riley, Walter-Verlag, 1985, pp. 291-294.

Döblin, Alfred. Berge Meere und Giganten. Suhrkamp Verlag, 2001.

Döblin, Alfred. "Futuristische Worttechnik: Offener Brief an F. T. Marinetti." Schriften zu Ästhetik, Poetik und Literatur, edited by Erich Kleinschmidt, WalterVerlag, 1989, pp. 113-119.

Goodbody, Axel. "Lehmanns 'Bukolische Tagebücher': Der Dichter als 'Nature Writer." Wilhelm Lehmann zwischen Naturwissen und Poesie, edited by Uwe Pörksen, Wallstein Verlag, 2007, pp. 51-67.

Harman, Graham. Immaterialism: Objects and Social Theory. Polity Press, 2016.

Harman, Graham. "The Well-Wrought Broken Hammer: Object-Oriented Literary Criticism." New Literary History, vol. 43, no. 2, 2012, pp. 183-203.

Harman, Graham. Weird Realism: Lovecraft and Philosophy. Zero Books, 2011.

Le Guin, Ursula K. "The Critics, the Monsters, and the Fantasists." The Wordsworth Circle, vol. 38, 2007, pp. 83-87.

Lehmann, Wilhelm. "Bukolisches Tagebuch aus den Jahren 1927-1932." Gesammelte Werke in acht Bänden: Band 8, edited by Verena Kobel-Bänninger, Klett-Cotta, 1999, pp. 175-309.

Lovecraft, H. P. "At the Mountains of Madness." The H. P. Lovecraft Omnibus 1: At the Mountains of Madness and Other Novels of Terror, Voyager Books, 1999, pp. 9-139.

Müller-Salget, Klaus. Alfred Döblin: Werk und Entwicklung. Bouvier Verlag, 1988.

Robertson, Ritchie. “Alfred Döblin's Feeling for Snow: The Poetry of Fact in Berge Meere und Giganten." Alfred Döblin: Paradigms of Modernism, edited by Steffan Davies and Ernest Schonfield, De Gruyter, 2009, pp. 215-228.

Ronen, Ruth. "Description, Narrative and Representation." Narrative, vol. 5, no. 3, 1997, Ohio State University Press, pp. 274-285.

Sander, Gabriele. "Alfred Döblin und der Großstadtrealismus." Realistisches Schreiben in der Weimarer Republik, edited by Sabine Kyora and Stefan Neuhaus, Königshausen \& Neumann, 2006, pp. 139-150.

Schäfer, Hans Dieter. "Naturdichtung und Neue Sachlichkeit." Die deutsche Literatur in der Weimarer Republik, edited by Wolfgang Rothe, Reclam, 1974, pp. 359-381.

Schäfer, Hans Dieter. Wilhelm Lehmann: Studien zu seinem Leben und Werk. H. Bouvier u. Co. Verlag, 1969. 
